\title{
Production of Controlled Low Strength Material Utilizing Waste Paper Sludge Ash and Recycled Aggregate Concrete
}

\author{
A. N. Azmi ${ }^{1, a}$, M. A. Fauzi ${ }^{1}$, M. D. Nor ${ }^{1}$, A. R. M. Ridzuan ${ }^{2}$ and M. F. Arshad ${ }^{2}$ \\ ${ }^{1}$ Faculty of Civil Engineering, Universiti Teknologi Mara, 13500 Permatang Pauh, Pulau Pinang, Malaysia \\ ${ }^{2}$ Faculty of Civil Engineering, Universiti Teknologi Mara, 40450 Shah Alam, Selangor, Malaysia
}

\begin{abstract}
Recently, the best method to make the concrete industry more sustainable was using the waste materials to replace the natural resources. Currently waste paper sludge is a major economic and environmental problem in this country. In this research, the alternative method is to dwindle the usage of natural resources and the usage of cement in the construction. This method is to replace the usage of cement with the waste paper sludge ash (WPSA) and to use the recycle aggregate collected from the construction is used. The WPSA has ingredient likely cement such as self-cementation but for a low strength. The research was conducted at heavy laboratory UITM Pulau Pinang. Meanwhile, the WPSA is collected at MNI Industries at Mentakab, Pahang. The recycle aggregate is a separated half, which were fine aggregate and the coarse aggregate with the specific size. In this research, the ratio is divided into two (2) which is $1: 1$ and $1: 2$ for the aggregate and difference percentage levels of WPSA. The percentage levels of WPSA that use in this research are $10 \%, 20 \%, 30 \%, 40 \%, 50 \%$, and $60 \%$. A total of 36 cubes were prepared. Aim of this research is to develop a simple design approach for the mixture proportioning of WPSA and recycle concrete aggregate (RCA) within the concrete and to assess the effect of concrete mix with different percentage of WPSA and RCA ratio on the properties. It is found that the best design mix that achieves control low strength material (CLSM) is on $30 \%$ of WPSA with the ratio 1:2 on day 28 of compression test.
\end{abstract}

\section{Introduction}

CLSM is a self-compacted or cementation material that used to backfill as an alternative to compacted fill. This type of material has several of names like flowable fill, lean-mix backfill, unshrinkable fill, flowable mortar, and controlled- density fill (CDF) but the name of Controlled Low Strength Material (CLSM) has been given by American Concrete Institute (ACI) Committee 229 [14]. CLSM is not a concrete and not also as soil cement, but it has the same properties of both. It cannot be considered as low-strength concrete, but can be considered as self-compacted backfill material that used as compacted fill. The combinations of the mixture to get CLSM are made of Portland cement, water, aggregate, and ash. The normally maximum compressive strength that achieve by CLSM is $8.3 \mathrm{MPa}$ from ACI Committee 229 [14].

The advantages use CLSM can reduced labor, fast construction and reduce the equipment use due to self-leveling properties and no need the compaction. While, for a low strength CLSM that range

\footnotetext{
${ }^{\text {a }}$ Corresponding author : najmifakhrudeen@gmail.com
} 
from 0.3 to $0.7 \mathrm{MPa}$ is allows for future excavation if needed. Other advantages for CLSM that used by product material such as fly ash and foundry sand that can reduce the utilizing of landfills. It was successful and more environmental when using by-product and waste materials to develop a sustainable development. On this paper, WPSA was use to replace the existing by product material to produce CLSM.

Malaysia government has been recently promoted sustainable development to achieve economic growth and a comfortable living for the next future generations. The most active activity in Malaysia that supports the local economic development is construction industries. The construction industries play an important role to develop and to build a comfortable living environment. The production of waste materials and the application of natural sources become negative impacts to this country [3]. The usage of natural sources is needed to be controlled before it's too late. The production of waste material especially from the construction industries need to be governed.

Singapore country nowadays forced to import the natural sources like an aggregate from overseas because their country shortage of the natural sources for their construction industries .Beside that, it would burden to the government and unable to achieve economic growth and comfortable living for the next future generations [3]. The most important material that use in construction industries is aggregates. In this study, the recycled material collected from the construction industries results from the demolited and renovated of buildings were used in the concrete mix. The recycled aggregate (RCA) was used as recycled material.

In this study, the RCA and waste paper sludge ash (WPSA) are used to get low strength called as control low strength material (CLSM). For RCA, it's collected from the batching plant and also can be used from demolition, renovated of building, roads and concrete must through the process that know as crushing.

RCA might be the best alternative solution to create a more sustainable concrete. It is due to the RCA have its own advantages like greater environmental awareness, achieve environmental laws, and keep the construction cost low. In terms of using RCA in structural concrete, Mohd Ridzuan et al. [1] reported that the use of 30\% RCA and 70\% natural aggregates in high strength concrete produces concrete of similar strength as that containing only natural aggregate. The plant-produced RCA as grainy in texture and later discussed that the RCA has a more rounded, spherical shape which seemed to improve workability [4].

Nowadays, natural construction material like aggregate was deficient. The production of natural aggregates causes of air pollution and environmental problem. WPSA is an innovation material that can be used in construction to replace the waste of cement. By utilizing WPSA, it may contribute Pozzolonic activity dependence on the percentage of WPSA after 7 and 28 days of concreting. Pozzolonic activity is very active where the alkalis and calcium hydroxide results from the mixing of concrete. The incineration of WPSA, when leached with alkali has potential as binder [3]. This study is to determine the strength of CLSM using WPSA in the CLSM mix as replacement of Portland cement. Table 1 show the chemical composition of WPSA and Portland cement based on the previous studies.

Table 1. Chemical Compositions of WPSA and Portland cement [8].

\begin{tabular}{|c|c|c|c|c|c|c|c|c|c|c|c|c|}
\hline $\begin{array}{c}\text { Chemical } \\
\text { properties }\end{array}$ & $\mathrm{SiO}_{2}$ & $\mathrm{Al}_{2} \mathrm{O}_{3}$ & $\mathrm{Fe}_{2} \mathrm{O}_{3}$ & $\mathrm{TiO}_{2}$ & $\mathrm{MgO}$ & $\mathrm{CaO}$ & $\mathrm{Na}_{2} \mathrm{O}$ & $\mathrm{K}_{2} \mathrm{O}$ & $\mathrm{P}_{2} \mathrm{O}_{5}$ & $\mathrm{MnO}$ & $\mathrm{SO}_{3}$ & LOI \\
\hline $\begin{array}{c}\text { WPSA } \\
\text { (\%) }\end{array}$ & 15.16 & 6.06 & 1.11 & 0.45 & 2.00 & 55.87 & 0.19 & 0.34 & 0.48 & 0.05 & 0.78 & 17.51 \\
\hline OPC (\%) & 15.05 & 2.56 & 4.00 & 0.12 & 1.27 & 72.17 & 0.08 & 0.41 & 0.06 & 0.06 & 2.90 & 1.33 \\
\hline
\end{tabular}




\section{Experimental Program}

\subsection{Preparation of materials}

To produce CLSM in this research, materials consist of WPSA, RCAs and soaked water (with RCA) were used. This CLSM unlike the ordinary mix and were produced with low strength same as lean concrete, brick and mortar. WPSA particles have wide range of size and composition and differ to Portland cement [2]. The WPSA was a waste material that collected from the paper industry at Mentakab, Pahang [1, 12, 13]. WPSA is used in this study as a replacement of cement to produce concrete. According to ASTM C618 for classification of fly ash, the WPSA classified as Class-C fly ash because the total combination percentage composition for major constituent components for silicon dioxide $\left(\mathrm{SiO}_{2}\right)$, aluminium oxide $\left(\mathrm{Al}_{2} \mathrm{O}_{3}\right)$ and iron oxide $\left(\mathrm{Fe}_{2} \mathrm{O}_{3}\right)$ more than $50 \%$ as shown in Table 1. Furthermore the WPSA contains higher of calcium oxide $(\mathrm{CaO})$ about $56 \%$ more than the requirement. Many researchers have proved that the self-cementing of class- $\mathrm{C}$ fly ash ability to modify the engineering properties due to its high calcium oxide $(\mathrm{CaO})$ content and pozzolanic characteristics without activators and more economic in stabilization application [9-11]. Hence, the WPSA was used as agent binder in the concrete mix due to pozzolanic composition.

The RCA was collected from recycled aggregates from demolished of and renovated of buildings, road and bridges. The RCA was crushed in the crushing machine and sieved in the sieving machine. The crushing machine was used to separate all materials such as coarse aggregate and fine aggregate. After concrete waste was crushed, the only coarses aggregates and fine aggregates through the next process known as sieving (grading). This process separated (graded) the size of aggregates to 4.75, $2.36,1.18,0.6,0.425,0.30,0.15$, and $0.075 \mathrm{~mm}$ by different of sieving pan. The next process is taking the course aggregates and fine aggregates by any size and quantity that measure it in the design mix to use for this paper study. The RCA size of $5 \mathrm{~mm}$ and $20 \mathrm{~mm}$ were used as recycled fine aggregate and recycled coarse aggregate respectively.

Prior to use the fine and coarse aggregates, they are soaked in distilled water to obtain the amount of alkali for the production of pozzolanic composition. RCA sizes $20 \mathrm{~mm}$ soaked in distilled water for 28 days to obtain complete concentration. PH meter was used and identified water containing high alkaline $\mathrm{pH} 12.2$ due to the pozzolanic reaction from the RCA. Alkali RCA released when soaked in water for 28 days the same study by Mohd Ridzuan et al. [1]. The water that containing high alkali was used back when the mixing process do, it can help pozzolonic reaction happen rapidly and have been proven by Abdullah et al. [7] .Two (2) series of concrete mixes was prepared using the WPSA, coarse and fine aggregate. Various ratio of WPSA investigated by batching all mixed with $0 \%, 10 \%$, $20 \%, 30 \%, 40 \%, 50 \%$ and $60 \%$ by total weight of aggregates. The mix proportions for all of the mix are based on the weight proportion of 1:1 and 1:2 (Fine RCA: Coarse RCA) on Table 2.

\subsection{Slump test}

Slump test was performed to measure the workability and consistency of the fresh concrete. Figure 1 shows the slump test that had been conducted. Which based on the BS 12350-2 [17].

\subsection{Compressive strength test}

The $100 \mathrm{~mm} \times 100 \mathrm{~mm} \times 100 \mathrm{~mm}$ sizes of cubes were used on this experiment. A total of 36 cubes were tested at the age of 7 and 28 days with accordance to BS 1881 [18]. A constant load rate of $0.6 \pm 0.2$ $\mathrm{N} / \mathrm{mm}^{2} / \mathrm{s}$ was used throughout the test. Two (2) series concrete mixes were prepared using WPSA, coarse aggregate and fine aggregate as shown in Table 2. 
MATEC Web of Conferences

Table 2. Mix proportion of CLSM.

\begin{tabular}{|c|c|c|c|c|c|}
\hline \multirow[b]{2}{*}{ Series (Ratio) } & \multicolumn{2}{|r|}{ WPSA } & \multicolumn{2}{|c|}{ RCA } & \multirow{2}{*}{$\begin{array}{c}\text { Water } \\
\text { Content (kg) }\end{array}$} \\
\hline & $\%$ & Weight $\left(\mathrm{kg} / \mathrm{m}^{3}\right)$ & Fine $\left(\mathrm{kg} / \mathrm{m}^{3}\right)$ & Coarse $\left(\mathrm{kg} / \mathrm{m}^{3}\right)$ & \\
\hline \multirow{6}{*}{$1: 1$} & 10 & 115 & \multirow{6}{*}{600} & \multirow{6}{*}{550} & \multirow{6}{*}{4} \\
\hline & 20 & 230 & & & \\
\hline & 30 & 345 & & & \\
\hline & 40 & 460 & & & \\
\hline & 50 & 575 & & & \\
\hline & 60 & 690 & & & \\
\hline \multirow{6}{*}{$1: 2$} & 10 & 113.3 & \multirow{6}{*}{396} & \multirow{6}{*}{737} & \multirow{6}{*}{4} \\
\hline & 20 & 226.6 & & & \\
\hline & 30 & 339.9 & & & \\
\hline & 40 & 453.2 & & & \\
\hline & 50 & 565.5 & & & \\
\hline & 60 & 679.8 & & & \\
\hline
\end{tabular}

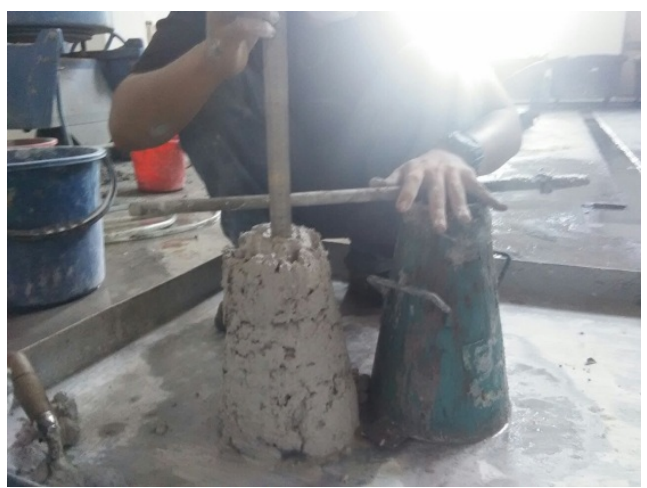

Figure 1. Slump Test (ratio 1:2).

\section{Results and Discussions}

\subsection{Slump test}

Workability of fresh concrete is influenced by its proportion. Table 3 shows the result of the slump of the fresh concrete. For the first ratio of $1: 1$, the concrete is totally collapse slump for all percentage of WPSA from $10 \%$ to $60 \%$ which is in the collapse range. The collapse range is between $150 \mathrm{~mm}$ to $250 \mathrm{~mm}$ collapse from the height of the cone. For this ratio $1: 1$, the workability mix is too high and too wet concrete based on the slumps. Figure 2 have shown the slump test ratio 1:1 that totally collapse.

For the second series of mix ratio of $1: 2$, indicates the fresh concrete is totally true slump as shown in Table 3. At this series, the slump for all percentage of WPSA from $10 \%$ to $60 \%$ were in the true slump range. The true slump range is between $50 \mathrm{~mm}$ and below that collapse from the height of the cone. For this ratio $1: 2$, the workability mix is too low and not too wet concrete based on the slump type. Figure 1 has shown the true slump of ratio 1:2. 
Table 3. Slump test results.

\begin{tabular}{|c|c|c|}
\hline Percentage of WPSA & Series 1 (Ratio 1:1), mm & Series 2 (Ratio 1:2), mm \\
\hline 10 & 218 & 45 \\
20 & 202 & 44 \\
30 & 223 & 31 \\
40 & 230 & 35 \\
50 & 242 & 42 \\
60 & 245 & 43 \\
\hline
\end{tabular}

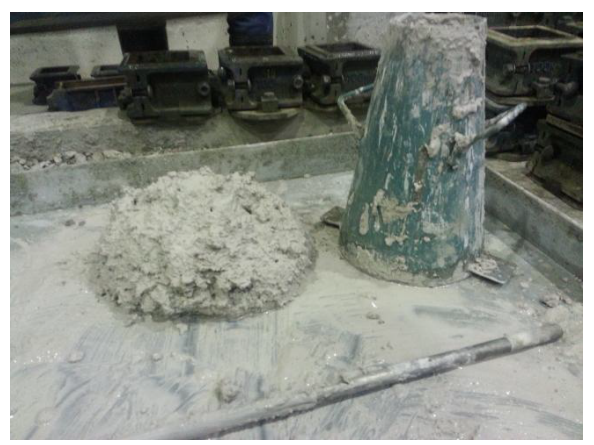

Figure 2. Slump Test (Ratio1:1).

\subsection{Compressive strength of CLSM concrete}

Figure 3 depicted the compressive strength of CLSM concrete at 7 and 28 days. It can be seen that the strength for all concrete mix are increased. Table 4 shows the compressive strength and density of the CLSM concrete at 7 and 28 days. It indicates that the density of the CLSM concrete affect to its performance. It is found that the compressive strength of the CLSM concrete is closely related to its weight.

Table 4. Compressive strength and density of CLSM concrete at 7 and 28 days.

\begin{tabular}{|c|c|c|c|c|c|c|}
\hline \multirow{3}{*}{$\begin{array}{l}\text { Percentage of } \\
\text { WPSA }(\%)\end{array}$} & \multicolumn{3}{|c|}{ Series 1 (Ratio 1:1) } & \multicolumn{3}{|c|}{ Series 2 (Ratio 1:2) } \\
\hline & \multicolumn{2}{|c|}{$\begin{array}{c}\text { Compressive strength } \\
\left(\mathrm{kN} / \mathrm{m}^{2}\right)\end{array}$} & \multirow{2}{*}{$\begin{array}{l}\text { Density } \\
\left(\mathrm{kg} / \mathrm{m}^{3}\right)\end{array}$} & \multicolumn{2}{|c|}{$\begin{array}{c}\text { Compressive strength } \\
\left(\mathrm{kN} / \mathrm{m}^{2}\right)\end{array}$} & \multirow{2}{*}{$\begin{array}{l}\text { Density } \\
\left(\mathrm{kg} / \mathrm{m}^{3}\right)\end{array}$} \\
\hline & 7 days & 28 days & & 7 days & 28 days & \\
\hline 10 & 3.014 & 3.752 & 2.13 & 2.604 & 3.224 & 1.90 \\
\hline 20 & 4.343 & 4.967 & 1.93 & 1.770 & 3.325 & 1.96 \\
\hline 30 & 3.222 & 3.855 & 2.00 & 6.346 & 6.425 & 1.96 \\
\hline 40 & 1.927 & 2.328 & 1.80 & 5.169 & 5.266 & 2.00 \\
\hline 50 & 1.362 & 1.832 & 1.83 & 4.972 & 5.235 & 1.90 \\
\hline 60 & 1.788 & 2.146 & 1.80 & 4.908 & 5.081 & 1.80 \\
\hline
\end{tabular}

For the series $1: 1$, the lowest strength of CLSM concrete is $1.832 \mathrm{kN} / \mathrm{m}^{2}$ with the dosage level of $50 \%$. Figure 4 shows the compressive strength of CLSM concrete at different percentage levels of WPSA. The optimum dosage level of WPSA as binder is $20 \%$ with the compressive strength of 4.967 $\mathrm{kN} / \mathrm{m}^{2}$. The higher the dosage level reduces the strength of the CLSM concrete. It might be the excess of the binder can reduce the pozzolanic reaction happen between binder and aggregates. 


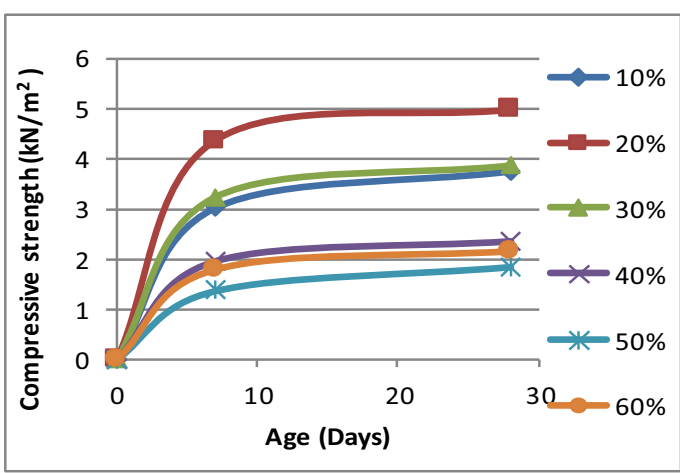

Figure 3. Compressive strength development for series $1(1: 1)$.

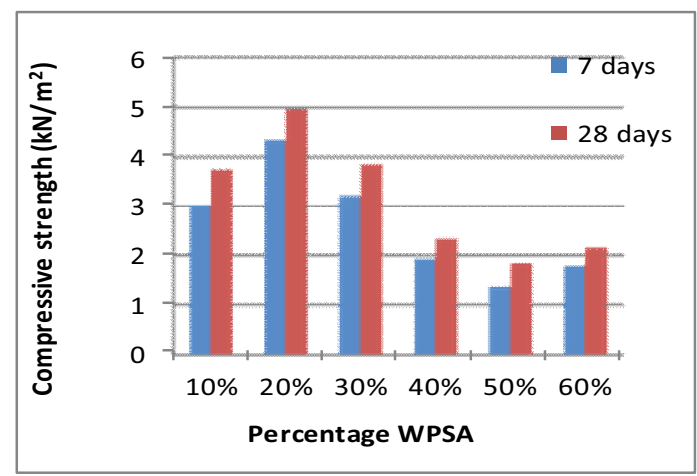

Figure 4. Effect of WPSA percentage for series 1 $(1: 1)$.

Figure 5 shows the compressive strength of CLSM concrete at the age of 7 and 28 days for various dosage levels of $10 \%$ to $60 \%$. While, the compressive strength of CLSM concrete at different percent for series 2 is presented in Figure 6 . The percentage of usage WPSA affects the hardening time process for 7 days until 28 days.

For the ratio 1:2, the lowest strength of CLSM concrete at 28 days is found to be at $10 \%$ WPSA of $3.224 \mathrm{kN} / \mathrm{m}^{2}$. While, the higher strength of this ratio is at $30 \%$ WPSA with the strength of 6.425 $\mathrm{kN} / \mathrm{m}^{2}$. The lowest strength of the CLSM concrete for series 1 and series 2 is at dosage level of $10 \%$ and $20 \%$, respectively. That means, 30\% WPSA mix is the high strength that achieve for the ratio 1:2.

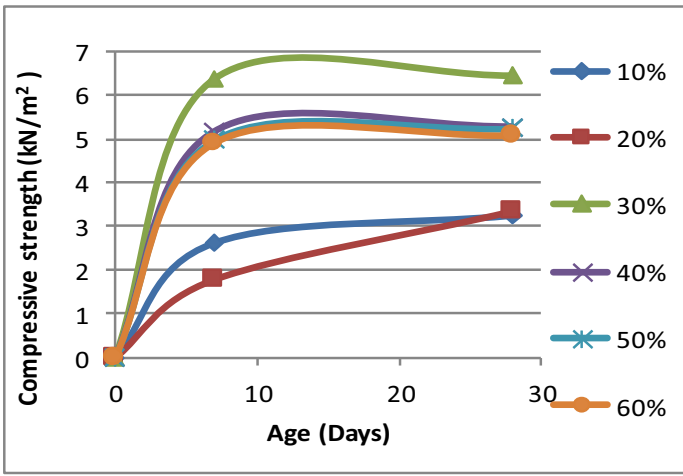

Figure 5. Compressive strength development for series $2(1: 2)$

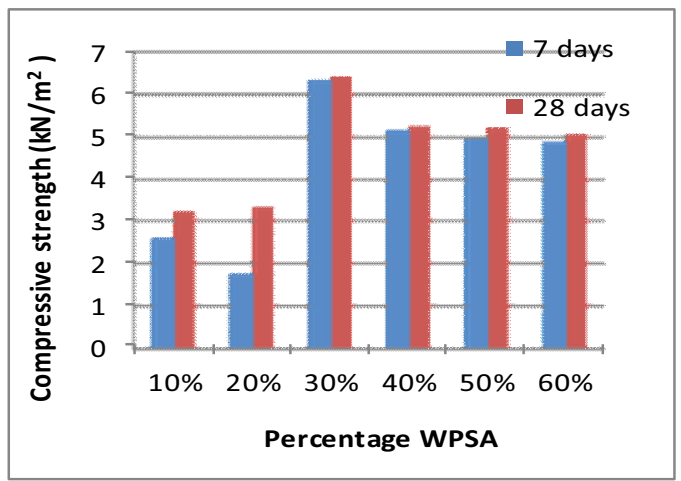

Figure 6. Effect of WPSA percentage for series 2 $(1: 2)$

The higher compressive strength is ratio 1:2 at dosage level of 30\% WPSA with the value of 6.425 $\mathrm{kN} / \mathrm{m}^{2}$. While, the lower ratio $1: 1$ at $50 \%$ WPSA with the strength of $1.832 \mathrm{kN} / \mathrm{m}^{2}$. Overall, the highest compressive strength is obtain at the age of 28 days for the both ratio and the all percentage of WPSA. This is because the concrete has been reached it mature strength on the 28 days after curing process. Besides that, the ratio for the highest strength is obtained. That ratio is $1: 2$ cubes that contain more coarse aggregate than the fine aggregate, it is more suitable to get the highest strength because this ratio contains more coarse aggregate which it restrains more loading. 


\section{Conclusions}

An investigation has been made of the strength characteristic of controlled low strength material (CLSM) by utilizing of recycled concrete aggregates and waste paper sludge ash. This is done using the compression machine and slump test to get the compressive strength and the slump (workability).

- The highest strength for both series was obtained at 28 days is $6.425 \mathrm{kN} / \mathrm{m}^{2}$ for $1: 2$ ratio with $30 \%$ of WPSA in the concrete mix.

- The best mix for this research is at the dosage levels of $20 \%$ and $30 \%$ of WPSA with the ratios of $1: 1$ and $1: 2$, respectively.

- It is found that the optimum compressive strength is using WPSA with ratio 1:2. Hence, it becomes the benchmark that would be used throughout the study at dosage level of $30 \%$.

- The workability of concrete mix decreases with the increase in WPSA content, it is suitable for flowable fill application based on ACI standard utilization.

- Utilization of WPSA in concrete would preserve natural resources that can be used for cement manufacture and thus make concrete construction industry sustainable. It also reduces emission of harmful pollutants into environment during the cement manufacturing.

- The compressive strength for ratio 1:1 and 1:2 is achieve the CLSM requirement according to ACI Standard 0.3 to $8.3 \mathrm{MPa}$ for flowable fill application.

\section{References}

[1] A.R. Mohd Ridzuan, M.A. Fauzi, E. Ghazali, M.F. Arshad and M.A. Mohd Fauzi, Strength assessment of controlled low strength materials (CLSM) utilizing recycled concrete aggregate and waste paper sludge ash, IEEE Colloquium on Humanities, Science and Engineering Research, 208-211, (2011).

[2] E. Mozaffari, M. O'Farrell, J.M. Kinuthia and S. Wild, Improving strength development of waste paper sludge ash by wet-milling, Cement and Concrete Composites, 28(2), 144-152, (2006).

[3] N.Y. Ho, Y. Pin, K. Lee, W.F. Lim, T. Zayed and M. Asce, Efficient utilization of recycled concrete aggregate in structural concrete, J. of Materials in Civil Engineering, 25(3), 318-327, (2013).

[4] K. McNeil and T.H.K Kang, Recycled concrete aggregates: A review, Int. J. of Concrete Structures and Materials, 7(1), 61-69, (2013).

[5] S.F.U. Ahmed, Properties of concrete containing construction and demolition wastes and fly ash, J. of Materials in Civil Engineering, 25(12), 1864-1870, (2013).

[6] N. Deshpande, S. Kulkarni and H. Pachpande, Strength characteristics of concrete with recycled aggregates and artificial sand, Int. J. of Engineering Research and Applications, 2(5), 38-42, (2012).

[7] A. Abdullah, M.S Jaafar, Y.H Taufiq-Yap, A. Alhozaimy, A. Al-Negheimish and J. Noorzaei, The effect of various chemical activators on pozzolanic reactivity: A review, Scientific Research and Essays, 7(7), 719-729, (2012).

[8] S.S. Sharipudin, A.R.M. Ridzuan and H. Mohd Saman, Performance of foamed concrete with waste paper sludge ash (WPSA) and fine recycled concrete aggregate (FRCA) contents, Int. Sustainability and Civil Engineering J., 1(2), 19-27, (2012).

[9] V. Sata, C. Jaturapitakkul and K. Kiattikomo, Influence of pozzolan from various by-product materials on mechanical properties of development and properties of low-calcium high strength concrete, Construction and Building Material, 21, 1589-1598, (2007).

[10]M.S.H.M. Sani, F. Muftah and M.A. Rahman, Properties of Waste Paper Sludge Ash (WPSA) as Cement Replacement in Mortar to Support Green Technology Material, The 3rd International Symposium and Exhibition in Sustainable Energy and Environment, 94-99, (2011).

[11]A. Misra, D. Biswas and S. Upadhyaya, Psysico-mechanical behaviour of self-cementing class C fly ash-clay mixtures, J. of Fuel, 84, (2005). 


\section{MATEC Web of Conferences}

[12]A.A. Khairulniza, Effect of alkaline activity to the strength and shrinkage performance of geopolymer concrete. Journal of Sustainability and Civil Engineering, (2012).

[13]A.R.M. Ridzuan, A.A. Khairulniza, M.A. Fadzil and J. Nurliza, Morphology and physical analysis of waste paper sludge ash (WPSA) polymeric mortar, Advanced Materials Research, 701, 275-279, (2013),

[14]ACI 229 R-99, Controlled low-strength materials, American Concrete Institute, (1999).

[15]BS EN 12390-2, Testing hardened concrete, Making and curing specimens for strength tests, British Standards, (2009).

[16]BS 410-1, Technical requirements and testing, test sieves of metal wire cloth, British Standards, (2000).

[17]BS EN 12350-2, Testing fresh concrete, slump-test, British Standards, (2009).

[18]BS 1881-108, Testing concrete, method for making test cubes from fresh concrete, British Standards, (1983). 